\title{
Beyond the Conventional Development Approaches: Evolving and Institutionalizing the Strategic Framework for Sustainable Wealth Creation and Development in Odukpani Local Government Area of Cross River State, Nigeria
}

\author{
Kelechi Elijah Nnamani* \\ Chukwuemeka Enyiazu \\ Ikemefuna Sunday Nwoke ${ }^{* *}$ \\ Ebere Dorothy Ochiaka \\ Joy Nkiru Agbo \\ Obinna Augustine Ovaga \\ Department of Political Science, \\ University of Nigeria, Nsukka, \\ Enugu State, Nigeria \\ *Email: Ikemefuna.nwoke@unn.edu.ng \\ ${ }^{\star *}$ Corresponding Author Email: kelechi.nnamani@unn.edu.ng
}

Doi: 10.2478/jesr-2019-0006

\begin{abstract}
Given the low level of economic development and the attendant burgeoning social vices at local level in Nigeria, this study illuminates on the strategic framework for sustainable wealth creation in Odukpani Local Government Area of Cross River State. The study argues that rather than the constant reliance on the 'one size fits all' analysis which has fundamentally blurred the minds of development experts and policymakers, greater emphasis should be placed on context-driven and specific studies. Among other things, the study notes that context-driven studies would enable each local government identify problems peculiar to it and evolve problem-solving measures consistent with local realities and demands. In the context of the present study, we share the optimism that Odukpani Local Government Council should prioritize wealth creation as basis for stimulating economic growth and development in the area. The study relies on triangulation of data involving interviews with key stakeholders, on-the-spot observation, participatory rural appraisal and information derived from relevant literature.
\end{abstract}

Keywords: Strategic Framework, Wealth Creation, Sustainable, Odukpani, Development, Context-Driven

\section{Introduction}

The general consensus in the body of development literature is that the top-bottom governance approach has achieved minimal and insignificant result in catalyzing genuine development in most developing states (Netabay, 2007; Okolie, 2009; Akpomuvie, 2010; Bonye, Aasoglenang \& OwusuSekyere, 2013). Therefore, it is believed that the multi-engagement of local people, resources and other relevant stakeholders in the development process in line with the dictates of bottom-up model is a sine qua non for not only speeding the slow pace of economic growth in the rural areas of 
peripheral societies but also engendering far-reaching and peoples-centered development. The justification necessitating this paradigm shift was largely due to the growing acceptance within the scientific community that bottom-up approach provides a coherent and broad-spectrum strategic framework for anchoring development programs in consonance with the existing circumstantial demands. It is further reinforced by the submission of Okolie (2009) which observed that the approach presents a unique opportunity for local players and citizens to express their opinion in defining the development course of their area in order to meet an expected outcome. In another study, Blanchard (1988) argued that bottom-up approach is renowned for generating development pattern which among other things, help in: localizing financial access, replicating human development, expanding learning opportunities, and enhancing comprehensive community participation.

Indeed, it was largely this idea which generated the demand for decentralization in most developing societies grappling with the challenge of effectuating genuine and result-oriented development programmes in a heterogeneous setting. As a political expedient denoting the dispersion and redistribution of functions, powers and authority from the central to local level, decentralization is seen to foster rapid development outcome. UN-Habitat (2009) argued that political decentralization to the local level is a critical element of democratization, good governance and citizens' engagement. In other studies, Faguet (2003) concretely observed that the decentralization initiative was central to the development efforts of Chile, China, Guatemala and Nepal while Conyers (1986) expressed optimism that some level of decentralization can go a long way in helping to advance some development objectives. Similarly, Faguet \& Pöschl (2015) noted that only local people who are conversant with problems in their locality can effectively initiate strategies and select appropriate priorities to tackle them.

More recently, the bottom-top governance strategy received further boost following the recognition by World Bank, Open Government Partnership and other development partners that the scope of governance should be broadened to enhance active participation of citizens in determining the dynamics of policy-making and implementation at the local level. This governance mechanism incorporates diverse opinions of all stakeholders of a public policy project such as citizens, public organizations, civil society organizations and private businesses into the implementation process. The rationale therefore, is that citizens should appropriate some powers over decisions that affect their progress and existence.

In Nigeria, although the idea of dispersing powers was historically traced to the pre-colonial administrations where powerful emperors and kings administered their subjects through the local chiefs (Asaju, 2010), it was the creation of the local government and its subsequent recognition as the third tier of government in 1979 which concretized the localization of governance for the benefit of the larger populace (Iseolorunkanmi, 2014). Meanwhile, the current decentralization arrangement in Nigeria was an offshoot of the formal transition from the military to democratically elected government which occurred on May 29, 1999 after over three decades of military rule. The 1999 Constitution of the Federal Republic of Nigeria (as amended) which heralded civil rule retained the status of local government as the third tier of government with powers to administer governance at the grassroot level. Specifically, Section 7 of the constitution provided that:

The system of local government by democratically elected government councils is under this constitution guaranteed, and accordingly, the government of every state shall, subject to the Section 8 of this constitution, ensure their existence under a law which provides for the establishment, structure, composition, finance and functions of such councils (Constitution of the Federal Republic of Nigeria, 1999: 5).

As a corollary, each State House of Assembly was constitutionally empowered to enact laws for the creation of local governments. In the context of the present study, the Cross River State House of Assembly promulgated the Local Government Law No. 1 of 2000 to provide for a presidential style of governance at the local level, involving separation of powers between the Executive and Legislature. By virtue of Section 3 (2) of the Local Government Law, the legislative duties were performed by the Councilors, periodically elected after every three years. Also, the executive powers are performed by the Chairman, Vice Chairman, Secretary of the Council, 
Supervisors, Special Advisers, and the whole machinery of local government bureaucracy. Most fundamentally, aside the constitutional provision which ensured that the local government generates chunk of revenue from statutory allocation, the third tier of government was further empowered to innovatively explore viable means of augmenting its financial base within their areas of jurisdiction. Again, both the federal and the state governments whether acting independently or concurrently, have developed and implemented programmes aimed at strengthening and supplementing the efforts of the local government in meeting the demands of governance at the rural areas. For instance, the Cross River State Government created both the Ministry of Local Government Affairs and the Rural Development Agency with a marching mandate to extend socioeconomic cum political development and good governance in the local areas.

Notwithstanding these efforts, emerging facts revealed that Odukpani like its counterpart local government councils in Cross River State is challenged by perennial issues such as poverty, scourge of HIVIAIDS, maternal and child mortality, absence of social services, unemployment and intertribal conflicts. As seen in the appendixes 1, $2 \& 3$, the prevalence of mud houses with thatched roofs in most communities in the area of study was largely attributed to the high incidence of poverty which has deprived the inhabitant access to decent homes. Most stakeholders in Odukpani local government attested that the high rate of unemployment among youths was responsible for the resurgence of cultism, militancy and inter-community clashes with devastating effects on the security of lives and property of the people. Also, there is an acceptance that the growing rate of illiteracy, poverty and unemployment may be associated with the high level of promiscuity among the youths, making them vulnerable to unwanted pregnancy and HIVIAIDS.

As these challenges persist, the Odukpani local government council has increasingly proved incapable of resolving the development problems inherent in its locality. Meanwhile, constraints imposed on the capacity of the local government to deliver its statutory functions have received substantial attention in the local government and public administration literature in Nigeria. An exploration of these studies reveal that scholars generally agreed that corruption, paucity of fund, lack of autonomy, non-emergence of genuine leadership, godfatherism syndrome and political interference, over-bloated bureaucracy with limited skilled personnel, and defective 1999 constitution remain the albatross to effective service delivery in Nigeria (Asaju, 2010; Oviasuyi, Idada \& Isiraojie, 2010; Abutudu, 2011; Coker \& Adams, 2012; Adeyemi, 2012; Akinola, 2013; Aleyomi, 2013; Ayogu \& Agboeze, 2014; Alao, Osakede \& Owolabi, 2015; Nwogwugwu \& Olusesi, 2015; Odalonu, 2015).

Although these studies are germane in appreciating the banes of local governance in Nigeria, the present study however argues that overemphasis on these variables in general term has continually blurred the minds of serious scholars from advancing a context-driven solution peculiar to a local government in Nigeria. We also believe that the problems of local governments in Nigeria cannot be generalized or studied from a unified binocular, as each has peculiar and disparate challenges which must be specifically identified and addressed in line with the existing socioeconomic realities. While paucity of funds may constitute the problem of a particular local government, others may be grappling with leadership deficit, political interference, corruption or poor management of resources. The consistent resort to one size fits all analysis prevent researchers from understanding the dynamics of political and socio-economic events that characterize local governments in Nigeria.

Therefore, the present study advances a model for understanding local governance in Nigeria using Odukpani Local Government as a point of departure. The idea of strategic approach for sustainable wealth creation was locally generated based on the needs, endowment, peculiarity and uniqueness of the local government under study. This area of thinking has remained largely unexplored in the existing studies and therefore, would open new and practical way of apprehending realities in different local governments in Nigeria. Most importantly, this study is mainstreamed into the post-2015 development agenda which shifted the focal point of development from national government to local stakeholders and actors (UNDG, 2015; Reddy, 2016; Halimi, 2016; Lebada, 2016). 


\section{A Foray into the Study Area, Materials and Methods Adopted}

Geographically, Odukpani Local Government Area is situated in the southern senatorial district of Cross River State, a province within the oil-rich region of Niger Delta. As seen in the map below, Odukpani local government lies between latitude $4^{\circ} 00 \mathrm{~N}$ and $5^{\circ} 00 \mathrm{~N}$ and $8000 \mathrm{E}$ and $8030 \mathrm{E}$ longitude and bounded in the south by Calabar Municipal, in the north by Biase local government area of cross river state, in the East by Akamkpa local government of Cross River state and finally in the West by Itu local government area of Akwa Ibom state. With an estimated population of 192,884 according to the 2006 census and a land area covering 2,624.6 square, Odukpani local government is touted as the second largest local government in Cross River state in terms of land mass.

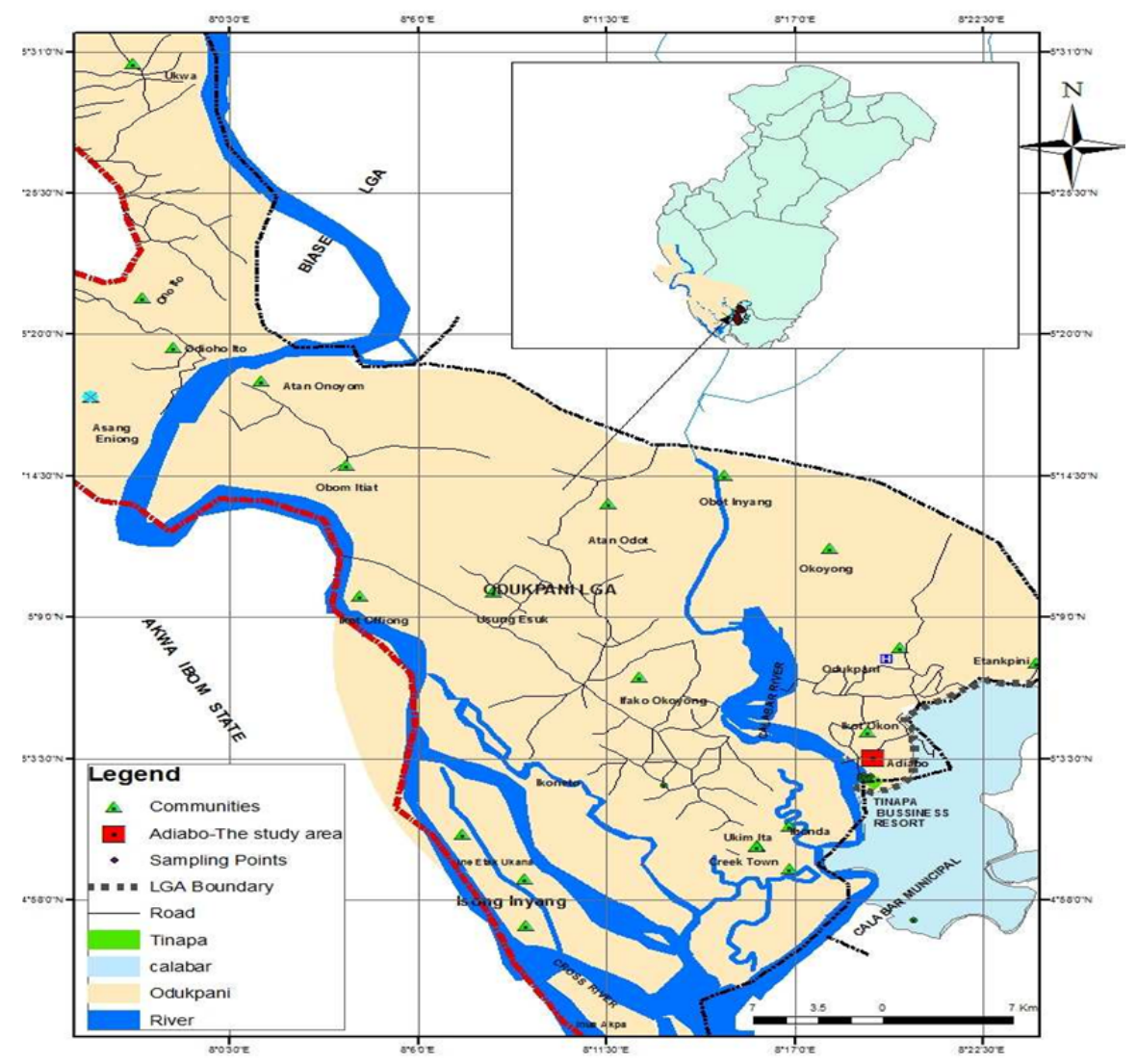

Fig. 3: Map of Odukpani

Politically, the local government is headquartered in New Netim and further divided into thirteen wards namely; Adiabo Efut, Akamkpa Okoyong, Ekong Anaku, Eniong, Eki, Obom Itiat, Odot, Odukpani Central, Onim/ankiong, Ikoneto, and Ito/Idere/Ukwa Wards. The governance of the local government is under an elected chairman who is the head of the executive and appoints other officials such as secretary of the council, chief of staff, supervisors of each department, Special advisers and executive assistants to assist in the formulation and execution of government policies. Also, each of the wards has elected councilor who makes law for the smooth and effective administrations of the council. Economically, the inhabitants are majorly farmers who take advantage of the arable lands to produce agricultural products such as cassava, maize, Okra, cucumber, and others in commercial quantity. Also, the citizens of Odukpani local government area 
take advantage of the abundant rivers for fishing purposes. Culturally, the area is mostly inhabited by the indigenous Efik ethnic group though other major tribes in Nigeria such as Ibibio, Igbo, and Yoruba are seen engaged in mostly trade and agriculture.

Meanwhile, the study is based on data triangulation derived from both primary and secondary sources since it involves of complex matters. Thus, We relied on four data collection techniques comprising documentary sources, interview, participatory rural appraisal and on-the-spot observation. Burnham et al (2004) argued that the best researches are those that utilized a combination of methodological approaches to deepen the research findings. We deployed the documentary method of data collection to elicit vital information already documented in books, book chapters, journals, official publications, newspapers and other online materials. Also, we utilized the on-the-spot observation method involving examination of field events, processes, relationships and people's perception. Specifically, the lead author utilized the one year mandatory national assignment to observe events in the local government. On the other hand, the participatory rural appraisal method is a technique that enhances effective participation by using marginal local resource person to elicit information. As such, useful information was gleaned from residents of the communities in the local governments. Issues examined were the level of underdevelopment in various communities in the study area as well as its implications on their livelihood. Also, the mass data gathered were analyzed using content analysis based on logical induction.

\section{Strategic Framework for Sustainable Wealth Creation in Odukpani Local Government Council}

Sound and strategic development template is a necessary requirement and cornerstone for resolving identifiable socio-economic and political challenges such as: unfriendly economic environment; unemployment; inequality; poverty; illiteracy; social vices; child and maternal mortality; and social vices at the local level. Thus, the United Nations Human Settlement Programme (2005) observed that local leaders and economic development practitioners need to have access to range of tools, ideas and experiences to help them strategically address their own complex issues at the local level. This is because, local challenges require local solutions. In scouting for local solutions, premium is placed on identifying a strategic model which offers relevant stakeholders such as government, labour, business and the poor an ample opportunity to assist in clarifying competitive advantages, identifying cooperative opportunities, crafting innovative options and generating strategies that better achieve local priorities.

Undoubtedly, numerous communities grappling with challenges of underdevelopment in Odukpani Local Government are in dire need of a coherent framework that will foster vibrant, resilient and sustainable local economies capable of improving the quality of life of people in their domain. In articulating this framework, the present study was essentially influenced and guided by the prevailing socio-economic cum political realities in the locality. Based on this, the under-listed are the strategic framework for sustainable wealth creation in Odukpani Local Government Area of Cross River state:

- Development and Implementation of Local Economic Development (LED) Agenda

- Mobilization of Adequate Human and Financial Resources

- Investment in Agriculture

- Establishment of Micro-Finance Banks

- Sustainable Tourism Development

- Establishment of functional market

- Establishment of skill acquisition scheme

\subsection{Development and Implementation of Local Economic Development (LED) Agenda in Odukpani Local Government Area of Cross River State}

Historically, the idea of Local Economic Development strategy was conceived in the high-income countries of North as a reaction to the social and economic problems which arose from the 
persistence of locality-specific development problems, characterized by the conventional top-down development approach, and supply-side sectoral development strategies in combating the ensuing rise in unemployment and regional inequality (Roberts, 1993; Nel, 2001). Nevertheless, Nel (2001) attributed the adoption and subsequent domestication of the LED development strategy in the developing world to the challenges of slow economic growth and poverty arising from the growing debt crisis, imposed structural adjustment and massive currency devaluation, and other natural and political shocks.

Since then, the LED strategic framework has not only occupied the centre stage of development initiatives, but widely recognized as a veritable and viable tool, model, strategy as well as feasible approach for accelerating the growth of local economies of the developing countries. In view of this development, the international donor agencies such as the International Monetary Fund, World Bank, Organization of Economic Cooperation and Development, United State Agency for International Development and the UK Department for International Development, have prioritized, promoted and advocated for the continual implementation of this framework as a cornerstone for achieving sustainable development in the low-income economies.

Although several scholars and multilateral institutions have made attempts to explain the concept of LED (Zaaier \& Sara, 1993; Blakely, 1994; Canzanelli, 2001; World Bank, 2003; Trousdale, 2005; World Bank, 2007), the present study for purpose of clarity and harmony identified salient variables which would enhance the understanding of LED. To us, LED is tripartite cum interdependent partnership or linkage existing between local government, private sectors and local communities in a given geographical area, aimed at building a resilient, competitive and sustainable local economy which would inexorably translate to poverty reduction, job creation and maximization of local material and human resources. Deriving from this definition is the recognition of interdependent interface and interaction which exist between key stakeholders as seen in the diagram below.

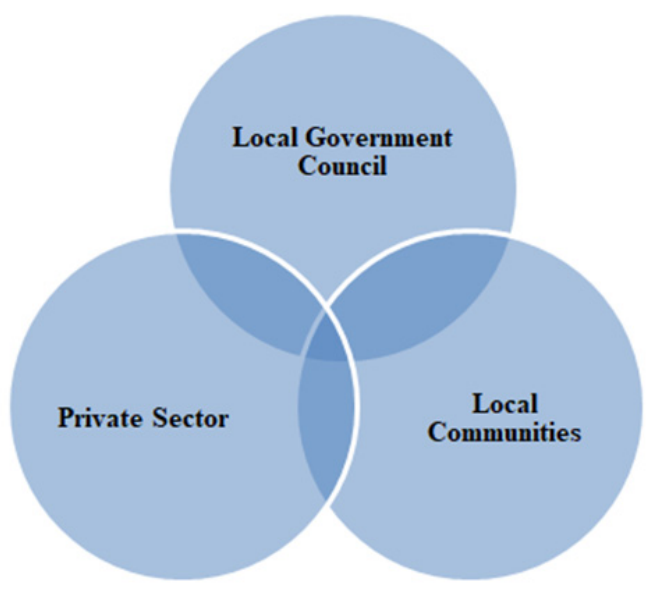

\section{Source: Researchers}

First, the interdependent linkage approximates LED as essentially a participatory and collaborative approach involving relevant stakeholders such as local government officials, civil society organizations, business investors, community and opinion leaders, and private citizens. The need for the participatory approach to development or governance stemmed from the growing belief that the task of building an economy especially at the local level is not an exclusive reserve of government and its officials but one in which the private sectors and the people have predominant role to play. Secondly, the key stakeholders must be residents of that locality so as to be attuned to the political, social and economic dynamics and realities of the area. Thirdly, the whole essence of 
LED framework according to World Bank (2003) is to build up the economic capacity of a local area, improve its economic future and the quality of life and create better conditions for economic growth and employment generation.

Like other development strategies, the Local Economic Development strategy is guided by certain principles as enunciated by the Education and Training Unit of South African Government. First, LED development strategy prioritizes job creation and poverty alleviation as its cardinal agenda. Second, LED development strategy is designed to target the disadvantaged and marginalized communities. Third, there is no single approach to LED as each locality may develop an approach that is consistent with a given local context and prevailing demand. Fourth, LED functions to promote local ownership, community involvement and joint decision making. Fifth, LED relies on flexible approach to respond to changing circumstances at local, national and international level. Finally, LED use local resources and skills to maximize opportunities for dev elopment (http://www.etu.org.za/toolbox/docs/government/led.html\#led).

As a coherent and systematic strategic framework, LED relies on the following steps outlined by World Bank:

STEP 1: Organizing the Effort: Successful LED depends on the collective efforts of the public, private and community sectors respectively. Formal and informal structures and processes should be established to ensure that all stakeholders are involved and the planning process is well managed. LED strategic planning commences by identifying the people, public institutions, community organizations, businesses and other groups with interest in the economy. The support, cooperation, skills and resources of each of the group is fundamental to the success of the whole program.

Step 2: Conducting the Local Economy Assessment: A thorough local economic assessment provides the foundation for successful LED strategy development. It involves collecting important information and then analyzing it strategically. Some information like the size and population of the area, employment status, number of educational institutions in the area, number of skilled and unskilled population, number and size of firms, number of foreign and domestic investment, taxation of businesses, existence of supporting business networks such as chambers of commerce, existence of basic infrastructural facilities are taken into cognizance. The major aim of local economy assessment is to critically identify the strength and weakness within the community that will either hinder or advance the economic development initiative.

STEP 3: Developing the LED Strategy: Here, the economic vision and action plan will be developed. This process enable the major stakeholders to define what is to be achieved, how to achieve it and when to achieve it.

STEP 4: Implementing the LEDS Strategy: Strategy implementation is driven by the LED action plans. Key issues to be considered are:

- Who takes responsibility for each program or project?

- What are the targets in terms of outputs, funding and timing?

- What steps need to be taken to achieve targets?

- What will be the reporting structures?

- What are the performance monitoring and evaluation system processes?

- What are the budgetary and human resource requirements for the sustained program or project?

STEP 5: Reviewing the LED strategy: Reviewing an economic development strategy is normally done on an annual basis, usually in conjunction with local financial authorities. An effective monitoring and evaluation technique helps to quantify outcomes, justify expenditures, determine enhancements and adjustments and develop good practices (http://www.worldbank.org/u rban/local/toolkit/pages/organizing-led-strategy.htm).

In Odukpani Local Government Area, our inquiry revealed that the developmental approach has consistently followed the traditional trajectory which negates the patterns and principles prescribed in the Local Economic Development plans. This essentially, was due to the inability of Odukpani Local Government Administrators, scholars or even development experts to evolve and inject this renowned development strategy in the planning process. However, in view of its 
enormous potentials in Odukpani Local Government Area, the present study suggests for a prioritization and systematic implementation of the Local Economic Development framework explicated above in the study area. Adoption and domestication of the LEDs model becomes imperative in the study area in view of its capacity to pursue an inclusive pattern of governance where the insight and capacities of the critical stakeholders who have been alienated in the development process will be leveraged to reduce poverty, unemployment and achieve an improved economy. These identified stakeholders are: the Odukpani Local Government Executives, Paramount Ruler, Councilors, Village Heads and Clans, youth and women leaders, indigent scholars, investors, top profiled civil servants both serving and retired, and public servants.

\subsection{Effective Mobilization of Adequate Financial and Human Resources}

Availability of revenue has been recognized as the livewire and tool for effective concretization of the development plans and objectives of any organization. In recognition of this undisputed truism, Ojo (2009) argued that any organization saddled with the responsibility of enhancing human welfare, development and creation of wealth for the citizens, protection of life and property and promotion of societal good through coordinated and cooperative efforts requires enough finance in order to achieve its target goals and objectives. As an organization, Odukpani Local Government Council has been constitutionally empowered to bridge the developmental deficits in the rural areas. Yet, efforts at bringing development to the local areas has been constrained due to the continuous shortfalls experienced in the revenue generated from the sale of crude oil (Nigeria's main source of income).

Based on the findings of the study which revealed total abandonment of the conventional means of revenue generation, we suggest for an upward and comprehensive review of the taxes, rents and other fees payable in the local government. These include: income and company tax, shops and kiosks rate, slaughter slab fees, marriage, birth, death registration fees, naming of street registration fees, right of occupancy fees on lands in the rural areas, signboard and advertisement fees, wrong parking charges, motor park levies, license fees e.t.c. Beyond this, an exploration of the innovative means of financing critical infrastructure and providing public goods is also a necessary requirement for addressing fund deficit in the local government. Firstly, the present study suggest for a funding model based on public private partnership (PPP or 3Ps).

The Public Private Partnership is a governance mechanism or arrangement between public authorities and the world of business which aim to ensure the funding, construction, renovation, management and maintenance of an infrastructure or provision of a service (European Commission, 2004). In this arrangement, the government and private sector enter into long-term collaboration on public buildings and critical infrastructure project with the ultimate goal of producing better and quality end products at lower cost. This financing arrangement if harnessed by the Odukpani local government council would, among other things, assist in providing certain facilities lacking in various communities as well as help government to channel the lean finance on other important areas requiring attention.

Secondly, given the availability of large expanse of arable lands in the study area, the local government council could in partnership with private sectors establish large scale, mechanized and commercialized farm in different areas with relative comparative advantage. For instance, an agriculturalist in the study area, Mr. Eyo Bassey remarked that Okonyong axis will be suitable for Maize and Cucumber farming, Odukpani central axis will go for plantain and Okra, Atan Eki axis will be appropriate for cassava, pineapple and yam while fishery and piggery will be suitable in Creek town which is a riverine area. Commercial cultivation of food crops and rearing of animal would not only enhance food sufficiency but also turn out to be a genuine source of revenue.

Thirdly, aside the aforementioned, the local government can boost their revenue generation through the acquisition of buses and cabs for commercial intra and inter transportation services. One of the authors, Nnamani Kelechi Elijah who spent one year in the study area decried the difficulty in conveying both goods and human beings within and outside the study area, largely due to absence of maintenance of an infrastructure of the provision of a service. Also, one of the farmers in Atan Eki, Mr. Akpan Antigha remarked that since he was constrained from moving his 
goods from the remote village to where he can exchange the agricultural products for money, he continues to record high rate of losses with concomitant manifestation in the expected income. Thus, setting an intra and inter bus and cab system to be managed by the local government council will not only improve the overall accessibility to the area of study, it will also help reduce the exorbitant charges of moving goods and services within and outside the local government, create jobs, and provide the necessary revenue through which the local government can fund some of its programs.

Also given the competitive nature of business environment where organizations and government establishments not only rely on the availability of material resources for the efficient coordination and management of its stated goals, human factor has been recognized as imperative and key to the realization of societal development. Indeed, the achievement of the foregoing is contingent on the creation of an institutional mechanism and process that will facilitate the recruitment, training and retraining of the workforce of the local government to ensure transparent collection, lodgment and safe-keeping of the generated revenue. In the same vein, the recruitment process must be merit-driven while the motivation of personnel should be accorded high premium.

\subsection{Investment in Agriculture}

The strategic role of agriculture in the overall development of a country and by extension, a region, has been overstretched and overemphasized in the existing literature (Bruce and Mellor, 1961; Kjeldsen-Kragh, 2006; World Bank, 2007; Meijerink and Roza, 2007; Cervantes-Godoy and Dewbre, 2010; Odetola and Etumnu, 2013; Omorogiuwa, Zivkovic and Ademoh, 2014). Agreeably, there is a general consensus that agriculture is the mainstay, backbone as well as the cornerstone of development initiatives in the low-income economies. Apart from providing food for the hungry, raw materials for industries and employment generation for the unemployed, agriculture now serves as a major source of revenue to most developing economies. No doubt, these perceived contributions of agriculture to local and national development was directly responsible for its integration in the policy prescriptions of both the defunct Millennium Development Goals, and the present Sustainable Development Goals.

Nigeria was previously renowned for its massive record in agricultural production particularly before the discovery of oil. Within this epoch, agricultural production was regionalized with the Northern region noted for groundnut, Western region known for cocoa while the eastern region was renowned for palm oil. Revenues earned from the exportation of these agricultural produce were used to finance critical infrastructural projects. In all, agriculture assumed a major contributor to the Nigeria's Gross Domestic Product, major source of foreign earning and employment for the teeming unemployed youths. Meanwhile, following the discovery of oil in commercial quantity and the concomitant huge revenue accrued from it, agriculture was relegated to the background in those areas where the country had comparative advantage. Since then, efforts at repositioning the agricultural sector to its former status have been unsuccessful.

Following the mainstreaming of agriculture into the post-2015 development agenda, the Nigerian governments at various levels have evolved and implemented policies aimed at making the sector commercially viable and lucrative. Most fundamentally, greater emphasis was channeled towards moving rural farmers from subsistence to profit-driven farming venture where the traditional practices of deploying crude implements would give way for more sophisticated ones. Although most local farmers in Nigeria have successfully transited from subsistence-based to commercial agriculture, our findings suggest that despite possessing rich and large expanse of arable land, local farmers in Odukpani area are still inclined to the use of crude implements. Amidst all these, the local government officials have been reluctant in evolving policies that would boost agricultural production in the area. While the study area is known for the production of essential products like palm oil, cucumber, maize, okra, cassava and coconut; extensive production has been hampered due to continuous reliance on traditional agricultural practices.

Indeed, this trend has tendentiously undermined poverty reduction, food sufficiency, and production of raw materials for industrial use. At least three farmers interviewed in the area of study highlighted some of the challenges facing agricultural rejuvenation. According to Oqua Asuquo, a 
farmer based in Eniong, the cost of procuring the modernized farming equipment is beyond his capacity as he hardly survives from the lean income generated from his farm. Also Mr. Essien Effiong while acknowledging financial constraint specifically identified lack of knowledge to effectively use modern equipments for farming. Supporting this line of thought, Mr. Essien Effiong whose position was translated by an indigenous research assistant observed that "most of us are illiterates and may not be able to deploy those modern facilities for farming purposes". Consequently, Mr. Ukpong Etim from Ito/Idere Ukwa axis also lamented on the increasing cost of procuring and maintaining modern agricultural facilities. On whether he will be willing to transit from crude implements to sophisticated equipments, Mr. Ukpong Etim noted that as a full time farmer whose existence is largely dependent on the annual produce from his farm, he will do everything possible to adapt to mechanized system of farming if only government can facilitate the procurement of those equipments and training of local farmers on how to deploy them for farming purposes.

In line with the foregoing, this study therefore believes that revamping agriculture as a critical component of the strategic framework for sustainable wealth creation in Odukpani Local Government Area can only be possible if greater emphasis is placed on the following:

a. Partnering with interested private investors to establish agro-based industries that will harness and optimally utilize the agricultural potentials, provide employment to the teeming population of the youths and generate income for the local government council.

b. Providing modern agricultural equipments, fertilizers and access to low interest loans to farmers

c. Opening up feeder roads in major communities like Eki, Ito/Idere/Ukwa, Pamol axis,

d. Training and deployment of agricultural extension workers to the rural areas to educate local farmers on modern agricultural practices like the use of improved seedlings, use of fertilizer etc.

e. Distribution of agricultural inputs and hiring out of farm equipments at a subsidized rate to the rural farmers.

f. Assisting cooperatives in rural areas to organize themselves for effective economic and political actions.

\subsection{Establishment of Micro-Finance Bank}

Robust economic growth as well as wealth creation drive aimed at addressing rural development deficit cannot be comprehensive without putting in place well focused program that increases access to credit facilities. Conceptually, micro-finance bank is a financial institution set up with the responsibility of extending small loans to individuals, businesses and organizations in low income regions, including underdeveloped countries where small amount of money can go a long way. Micro-finance bank exist to provide microloans or credits facilities to people who are unable to access capital from other financial institutions. These loans foster the development of small businesses and help local entrepreneurs to fulfill their dreams. A micro-finance is also involved in social investing i.e. fostering the growth and economic development in vulnerable regions by extending credit facilities to families, farmers, businesses and entrepreneurs.

In Nigeria, an official report released by the Central Bank of Nigeria in 2010 indicates that there was a marginal increase of those served by the formal financial market from 35.0 percent in 2005 to 36.3 percent in 2010 , five (5) years after the launching of the microfinance policy. When those that had financial services from the informal sector such as savings clubs/pools, Esusu, Ajo, and money lenders were included, the total access percentage for 2010 was 53.7 percent which means that 46.3 percent or 39.2 million adult's population were financially excluded in Nigeria. As an integral constituent of Nigeria and based on the report submitted above, Odukpani is among the many local governments without either the macro or micro finance institutions despite its proximity to the capital of Cross River State. Although microfinance banks were established to boost the informal sector in the developing economies where poverty, unemployment and other social crises are ravaging the citizens, the absence of financial institution in the study area has greatly undermined entrepreneurial and agricultural activities in Odukpani local government area. 
The unavailability of credit facilities has discouraged the operation and development of small and medium scale businesses and service firms. Indeed, most entrepreneurs who had vision of engaging in one productive venture or another as a way of boosting the economic growth, creating job opportunities in the informal economy and achieving the SDGs, has been constrained due to lack of access to credit facilities. For instance, an indigene of Adiabo Efut, a village close to Tinapa Resort, Mr. Samuel Ekpenyong lamented that his idea of building and owning a modernized poultry farm crumbled at incubation stage due to lack of access to credit facilities. Buttressing his point in a local adage, he posited that: 'you don't expect one to climb a palm tree successfully without the assistance of a locally made rope else he will fall down' literally meaning that one should not expect a visionary entrepreneur to achieve his laudable business proposal without access to credit facilities. Also, Mrs. Alice Etim who specializes in the making of confectionaries remarked that her quest to expand the business was hindered due to lack of access to credit facilities. She narrated that most commercial banks she had approached in Calabar for loan facility turned down her request due to what they termed as non-viability of the business while others demanded for stringent collateral in exchange for the loan.

In view of the immense losses arising from inaccessibility of credit facilities in the locality, the present study suggest for a strategic partnership between the local government council and private institution which would ultimately lead to establish a microfinance bank. The micro-finance bank which would either be wholly or partially owned by the local government will facilitate easy access to credit facilities by easing the stringent measures and conditions usually experienced with the commercial banks as well as boosting the economic well being of the people.

\subsection{Sustainable Tourism Development}

Tourism is key to the development, wellbeing and prosperity of the world especially the developing countries. Although frequently neglected and underrated, the tourism sector has acquired significant importance in the areas of providing jobs, generating wealth, diversifying the economy, protecting the environment and promoting cross-cultural awareness in the developing countries (Honey \& Gilpin, 2009). This development no doubt can be attributed to the phenomenon of globalization which has dismantled barriers to movement of people and goods from one country to another. As people move from one state to another, there are bound to spend money on hotels, food, transportation, monuments, historic sites and place of relaxations. By making these payments, substantial revenues are generated while greater investments in infrastructure are pursued, thereby contributing to the improved living conditions of the people. Available data reveals that:

the international tourism receipts earned by destinations worldwide have surged from US\$2 billion in 1950 to US\$ 104 billion in 1980, US\$ 495 billion in 2000, and US\$ 1260 billion in 2015. International tourism now represents $7 \%$ of the world's exports in goods and services, up from $6 \%$ in 2014, as tourism has grown faster than world trade over the past four years. As a worldwide export category, tourism ranks third after fuels and chemicals and ahead of food and automotive products. In many developing countries, tourism ranks as the first export sector (UNWTO, 2016: 2).

With these benefits in mind, the United Nations identified and integrated the development of tourism as one of the means the developing countries might meet with the Sustainable Development Goals (http://icr.unwto.org/content/tourism-and-sdgs). Interestingly, the Cross River State under the administration of the then Governor Donald Duke explored the tourism potentials in the state and invested massively in the sector, culminating into the development of major tourist destinations such as Tinapa Business and Leisure Resort in Odukpani, Obudu Mountain Resort in Obanlinku, Agbokim Waterfall in Ikom, Kwa Falls in Akamkpa, and among others.

Aside the Tinapa Resort, many unexplored and undeveloped natural habitats still abound in the local government, which if developed, would attract tourists and spur the economic activities in the area of study. For instance, the development and sustenance of the following historical monuments and natural habitats such as the Mary Slessor's house in Okoyong, Twin Island in Creek Town, resting homes of major missionaries and colonial rulers, Waterfall at Odukpani 
Central, prefabricated houses in Creek Town and other places of relaxation, would boost tourist activities in the study area. A public-private partnership model between the local government and the private investors as proposed by Droli (2008), Teker and Teker (2012), Ekpenyong and Mmom (2015), Venkateswarlu and Jayalakshmi, (2016), is required to develop and maintain the aforementioned tourism potentials in Odukpani Local Government Area of Cross River State.

\subsection{Establishment of Functional Market in Odukpani}

Functional local market is critical to spurring the growth and development of local economies. It is a platform that connects rural to urban, farmers to consumers and fresh ingredients to diets. When edible or non-edible items are produced, processed, distributed and sold all within the same region, more money stays in the local economy, thereby leading to economic development and job creation. Local markets provide opportunities for traders, farmers and other businesses to sell their products in order to meet the growing demand for locally produced goods and services. Aside the immense benefits enjoyed by the traders and buyers, the fee usually generated from stall owners also serve as veritable source of revenue for the local government.

Nevertheless, the observation of the study reveals that while other local governments in Cross River State such as Akamkpa, Biase, Calabar Municipal and Calabar South can boast of functional market where locally made goods and services can be traded, Odukpani Local Government exists without one. The implication of this development is that many farmers and traders rely on the markets provided by other local governments to trade their produce and goods. As a corollary, the present study believes that four different markets should be constructed by the local government in partnership with financial institutions in four political wards including Okonyong, Odukpani Central, Eki and Creek Town. The presence of market in the local government council would not only save people the stress and cost of traveling to Calabar, Akamkpa and Biase, but will also boost the economic activities of the area by generating more incomes to both the people and government.

\subsection{Establishment of Skill Acquisition Centers}

Access to vocational skills and technical know-how are parts of the strategies designed to halt the surging rate of poverty and unemployment particularly among youths and women in the Agenda 2030. As a local government with teeming population of unemployed youths, Odukpani local government has been a fertile ground for militancy, restiveness, cultism and armed robbery. Expectedly, this development creates platform for the co-option of youths as agents for orchestration of heinous acts against the state. To counteract this trend, the study believes that the local government council should collaborate with relevant agencies at federal and state level as well as private sectors, to establish skill acquisition centers where youths would be exposed to different vocations and made useful to the society. The skill acquisition project should among other things include: shoe-making, welding, brick-laying, masonry, baking and horticulture.

As a pilot project, Nnamani Kelechi Elijah, one of the researchers as seen in fig. 5, 6, \& 7 organized a skill acquisition project in Eseku village Creek Town in Odukpani Local Government Area where participants especially women were exposed to the practical art of making confectionaries and beverages. This was initiated as part of the efforts aimed at engaging the women and youths productively in order to contribute in creating sustainable wealth in Odukpani Local Government Area of Cross River State. Participants at the Skill Acquisition Program include: Wife of the then Acting Governor of Cross River State, Her Excellency, Mrs. Glory Efiok Cobhams; the General Manager of Cross River State Micro Finance \& Enterprise Development Agency, Mr. Louis Ibok; Councilor representing Creek Town II in Odukpani Local Government Legislative Council, Rt. Hon. Ani Ekpeyong; Women of Eseku village; and Members the of National Youth Service Corps (NYSC). 


\section{The Role of Odukpani Local Government Council in the Actualization of the Strategic Framework}

Scholars from liberal and neoliberal strands have constantly argued that the state instead of ultimately deciding what to produce, how to produce and when to produce should rather, limits its functions to maintenance of law and order as well as creating enabling environment that allow the forces of demand and supply to play this vital role due to obvious advantages accruable from the process. This perspective has been contested by analysts from the developing countries who opined that alienating the state would inevitably lead to the underdevelopment of productive forces believed to be at the rudimentary stage. However, this scholars favoured an interventionist approach, one in which government plays preponderant role in the economy.

To this present study, the government, the people and the private sector are joint stakeholders in the development process at the local level. Also given that wealth creation is an interdependent activity involving diverse interests whose respective roles are fundamental to the achievement of the goals. In this context, we state that the task of creating wealth in Odukpani local government area is essentially dependent on the resolve by the host government to champion the initiative from hatching, embryonic to matured stages. Succinctly put, the host government is expected to provide the necessary facilities and supports that encourage all the relevant stakeholders including but not limited to community and opinion leaders, civil society groups, foreign and local investors as well as religious groups, to contribute in the shaping of developmental policies.

As a corollary of the foregoing, the under-listed are the roles expected of Odukpani local government council in the actualization of the development programs as adumbrated in the previous section:

a. Creation of Enabling Environment: It is axiomatic to state that since development is context-driven, there are socio-economic cum political variables that shape and affect its adaptability and by extension, its sustainability. Thus, the success of any developmentdriven models particularly at the local level is largely dependent on the willpower of the local government to create a favourable environment for economic activities to thrive within the locality. Firstly, it is the duty of the local government officials to create a business-friendly environment through the enactment of relevant laws that harmonize taxation, land access and ownership. Secondly, investors can be lured into setting up industries in a particular area if certain basic amenities and infrastructural facilities such as accessible roads, standard schools, affordable and quality health services, hotels of international standard, potable drinking water, adequate security, consistent power supply, efficient transportation system and adequate housing were provided by the local government. Thus, Odukpani local government council must prioritize the provision and availability of the aforementioned social services as a way of attracting both local and foreign investment.

b. Partnership with Federal and State Governments: Federalism is an arrangement that offers the three levels of government the platform to work coordinately in order to achieve goals which ordinarily would not be achieved by a single tier. As an integral part of federal system, it behooves the Odukpani local government council to draft a workable development template consistent with the aspirations and yearnings of the people which must be pursued and actualized through strategic partnership with the central and state governments.

c. Partnership with International Developmental Agencies: Since the inception of the present globalized world order, the international development partners have evolved and implemented programs aimed at addressing the perennial development challenges in the rural areas of developing countries. Organizations and institutions such as World Bank, International Monetary Fund, United Nations Development Programmes, Department for International Development, United State Agency for International Development and among many others, have supported development agenda in many states and local governments in Nigeria. Considering the rate of poverty and infrastructural decay in the study area, the Odukpani council officials through a well researched, articulated and feasible proposal can 
attract financial and technical assistances from the international institutions and organizations for pursuit and actualization of development programs.

d. Partnership with Civil Society Organizations and Private Sector: The civil society organizations and private sectors have played historical roles in the socio-economic and political development across the globe which earned it the title of the 'third sector' distinct from public and private sectors. Starting from early 1980s, only few organizations responded to the obvious vacuum created by misgovernance in some peripheral societies and assumed responsibilities hitherto created by the governments. Henceforth, the civil society organizations have been strategically positioned to financially and technically assist the poor communities in the developing regions in their quest for rediscovery and self development. Also, since the collapse of the Communist-Soviet Union and subsequent emergence of a neoliberal-governed world order, the private sector has increasingly assumed and exerted preponderant influence in not only determining and shaping the locus of global development policies but has equally participated through their active and direct engagement, in implementing development-oriented reforms and offering development assistance to most developing societies. Through public-private partnership initiatives, corporate social responsibilities and private sector-driven trade activities, jobs have been created, critical infrastructure have been built, local economies have been revamped, moribund industries have been resuscitated, while sustainable economic growth have been achieved. Thus, it is the duty of the Odukpani local government to develop a framework that will facilitate strategic partnership with both private sectors and civil society organizations as way of reaping the benefits derivable from the process.

e. Responsible and Responsive Government: In the present global system, greater focus has been shifted to creating institutions that promote rule of law, service delivery, accountability and transparent management of government's businesses. As a corollary, a responsible government remains a decisive factor in attracting the attention of international organizations, development partners and private sectors for development assistance. A responsible government is one which is responsive to the needs, aspirations and yearnings of the governed and enthrones accountability and transparency in its businesses. In the context of this study, we propose that the institutionalization of internationally accepted or best practices in running affairs of the Odukpani local government council would inexorably attracts the support of relevant development partners. As a way of demonstrating the necessity for a responsive government in the attainment of development programs of the local government, one of the researchers Nnamani Kelechi Elijah during a courtesy visit to the Odukpani Legislative Council as seen in fig. $7 \& 8$, harped on the need for local government legislature to deploy legislative instruments to build institutions of governance that promotes rule of law, inclusiveness, equity, development, participation, accountability, and rule of law.

f. Marketing of the Local Government Council: The interconnectedness of the world occasioned by the information revolution and the extraordinary increase in the spread of knowledge have ushered in a new era; one of knowledge and information which affects directly economic, social and political activities across the regions of the world. Governments all over the world have acknowledged the indispensable role that information communication technology could play in the societal socio-economic development. Faye (2000) observed that ICT are offering the developing economies a window of opportunities to leapfrog the industrialization stage and transform their economies in high value-added information economies that can compete with the advanced economics on the global market. In the context of the present study, the Odukpani local government council can leverage from this historical technological innovation to showcase its natural endowments, agricultural produce, cultural heritage and people through the World Wide Web (WEB). 


\section{Conclusion}

The present study maintained that efforts at humanizing the challenges of development in local government should be context-driven since each local government has peculiar problems distinct from others. Adopting a uniform approach to the challenges of local government in Nigeria is bound to be counterproductive. However, each local government should be studied and analyzed to identify problems peculiar to it while locally-driven measures should be generated to manage the identified challenge(s).

In view of this present study, we embarked on a coherent, comprehensive and systematic investigation of the impediments to development of Odukpani local government area based on the realities on ground. At the interim, the study found that like most local government areas in Nigeria, Odukpani is still grappling with challenges of development manifesting in abject poverty induced by massive unemployment, illiteracy, HIVIAIDS, malaria, food insecurity, low productivity and others. The present study taken cognizance of the myriads of the aforementioned problems argued that the solution lies in the development and implementation of strategic framework for sustainable wealth creation and development which is consistent with the peculiarities and realities of the study location. These strategies include: development of LEDs, the establishment of microfinance banks, massive investment in agriculture and tourism, building of critical infrastructure, and development of the efficient transportation system. Also the paper identified some of the roles of the local government council in achieving the goals. Accordingly, the study believes that the Odukpani Local Government Council should among other things, champion the course of creating an enabling environment; partner with other levels of government, civil society organizations and private sectors and utilize the opportunities offered by the technological progress made to market the potentials of the local government to the international community. Indeed, the implementation of development goals based on the foregoing would inexorably assist in the advancement of the visions that necessitated the creation of Odukpani Local Government Area.

\section{Acknowledgements}

We sincerely appreciate Professor Aloysius-Michaels Okolie, an academic par excellence and our mentor, whose scientific output and intellectual insight has continued to serve as an inspiration and guide to us. Rt. Hon. Ani Ekpeyong Asuquo, Her Excellency Mrs. Glory Efiok Cobham, Joy Ita, Atim Alice and Mrs. Ekanem Antigha were indigenes of Odukpani who provided the motivation and relevant information without which this study would have been a mirage.

\section{References}

Abutudu, M. (2011). The challenges and opportunities for improving the local government system in Nigeria. A Paper presented at the Third Biennial National Conference on Community Development in Nigeria Held at Grand Hotel, Asaba, November, 20-24, 2011.

Adeyemi, O. O. (2012). Corruption and local government administration in Nigeria: A discourse of core issues. European Journal of Sustainable Development (2012), 1, 2, 183-198 ISSN: 2239-5938.

Akinola, B. (2013). Problems and prospects of local government administration in Nigeria during the 21st century. Social Science and Law Journal for Policy Review and Development Strategies Vol. 3, No. 3, August 2013. Pg. 95-103.

Akpomuvie, O. B. (2010). Self-help as a strategy for rural development in Nigeria: A bottom-up approach. Journal of Alternative Perspectives in the Social Sciences (2010) Vol 2, No 1, 88-111.

Alao, D. O., Osakede, K. O. and Owolabi, T. Y. (2015). Challenges of local government administration in Nigeria: Lessons from comparative analysis. International Journal of Development and Economic Sustainability Vol.3, No.4, pp.61-79

Aleyomi, M. B. (2013). Local government administration in Nigeria: A review. Africana Vol. 6, NO. 234.

Asaju, K. (2010): Local government autonomy In Nigeria: Politics and challenges of the 1999 constitution. International Journal of Advanced Legal Studies and Governance vol. 1 No.1, April 2010.

Ayogu, G. I. \& Agboeze, M. U. (2014). Revitalizing local governments for community development in Nigeria: Problems and wayfoward. Interdisciplinary Journal of Contemporary Research in Business. Vol. 5. No. 9. 
Blakely, E.J. (1994). Planning local economic development: theory and practice. 2nd ed. Newbury Park: Sage Publications.

Blanchard, D. (1988). Empirical strategies of bottom-up development. ICA International IERD Regional Development Svmposia. pp. 318-338

Bonye, S. Z., Aasoglenang, A. T. \& Owusu-Sekyere, E. (2013). Community development in Ghana: theory and practice. European Scientific Journal vol.9, No.17.

Bruce F. J. \& Mellor, J. W. (1961). The role of agriculture in economic development. The American Economic Review Vol. 51, No. 4 (Sep., 1961), pp. 566-593.

Burnham, P., Lutz, K. G., Grant, W. and Layton-Henry, Z. (2004) Research Methods in Politics. Basingstoke: Palgrave Macmillan. p. 8.

Canzanelli, G. (2001). Overview and learned lessons on local economic development, human development and decent work. Universitas, Working Papers, 2001, p.9.

Central Bank Nigeria (2005). Microfinance policy regulatory and supervisory framework for Nigeria. Abuja: CBN.

Central Bank of Nigeria (2010). Microfinance. Retrieved from https://www.cbn.gov.ng/devfin/microfinance.asp, on $13^{\text {th }}$ October 2017.

Central Bank Nigeria (2011). Microfinance policy regulatory and supervisory framework for Nigeria. Abuja: CBN. Revised Edition.

Cervantes-Godoy, D. and J. Dewbre (2010). Economic importance of agriculture for poverty reduction. OECD Food, Agriculture and Fisheries Working Papers, No. 23, OECD Publishing. doi: 10.1787/5kmmv9s20944en

Coker, M. A. \& Adams, J. A. (2012). Challenges of Managing Local Government Finance in Nigeria. Research on Humanities and Social Sciences, Vol.2, No.3, 2012.

Conyers, D. (1986). Decentralization and development: A framework for analysis. Community Development Journal, Volume 21, Issue 2, 1 April 1986, Pages 88-100, https://doi.org/10.1093/cdj/21.2.88

Droli, M. (2008). Tourism development: From public-private partnership (PPP) to PPPartnering (PPP-ing). Turismo d'Italia, National Hotelier Association Review, No. 81, January-February, 2008.

Ekpenyong, O. \& Mmom, P.C. (2015). Public-private partnership and tourism development in the Niger Delta Region. Journal of Environment and Earth Science. Vol. 5, No.2, 2015.

European Commission (2004). Green paper on public-private partnerships and community law on public contracts and concessions. COM (2004) 327 Final. European Commission Brussels.

Faguet, J. (2005). The effects of decentralization on public investment: evidence and four lessons from Bolivia and Colombia. Crisis States Programme Working Papers Series No. 1

Faguet, J. \& Pöschl, C. (2015). Is decentralization good for development? Perspectives from academics and policy makers. Oxford, England: Oxford University Press, 2015, pp. 1-29.

Federal Republic of Nigeria (1976). Guidelines for local government reform. Government Printing Press. Kaduna.

Federal Republic of Nigeria (1999). Constitution of the Federal Republic of Nigeria, 1999 as altered 2011. Government Press, Abuja.

Halimi, H. (2016). SDGs and the role of local governments. Retrieved from https://www.urbanafrica.net/resource s/the-localisation/, on 22/08/2018.

Honey, M. \& Gilpin, R. (2009). Tourism in the developing World: Promoting peace and reducing poverty. United States Institute of Peace Special Report. Retrieved from https://www.usip.org/sites/default/files/tour ism_developing_world_sr233.pdf, on 17/03/2018.

Igwebuike, G. A. \& Ugwu, M. A. (2014). Revitalizing local governments for community development in Nigeria: Problems and wayfoward. Institute of Interdisciplinary Business Research VOL 5, NO 9. Pg. 534-550.

IseOlorunkanmi O. J. (2014). Decentralization, local governance and public goods delivery in Nigeria. International Journal of Public Administration and Management Research (IJPAMR), Vol. 2, No 2, March., 2014

Kafle, S. \& Karke, K. (2003). Towards ideal local government: Strengthening participatory development. Unpublished Memoir.

Kjeldsen-Kragh, S. (2006). The role of agriculture in economic development: The lessons of history. Copenhagen Business School Press, Denmark.

Lebada, A. M. (2016). Local governments, UN agencies launch roadmap for localizing SDGs. Retrieved from http://sdg.iisd.org/news/local-governments-un-agencies-launch-roadmap-for-localizing-sdgs/, $\quad$ on $12 / 10 / 2018$.

Nel, E. (2001). Local economic development: A review and assessment of its current status in South Africa. Urban Studies, 38(7), 1003-1024.

Netabay, N. (2007). Bottom-up approach: A viable strategy in solving the Somali conflict. Retrieved from http://www.beyondintractability.org/casestudy/netabay-bottom, on $10^{\text {th }}$ June 2016. 
Nwogwugwu N. \& Olusesi, T. A. (2015). Operation of State-Local Governments Joint Account and Financial Autonomy of Local Governments in Nigeria's Fourth Republic. International Journal of Innovative Research \& Development, Vol. 4 Issue 11. Pg. 85-91.

Meijerink, G. \& P. Roza. (2007). The role of agriculture in development. Markets, Chains and Sustainable Development Strategy and Policy Paper, no. 5. Stichting DLO: Wageningen.

Odalonu, H. B. (2015). Challenges confronting local government administration in efficient and effective social service delivery: The Nigerian experience. International Journal of Public Administration and Management Research (IJPAMR), Vol. 2, No. 5, March 2015.

Odetola, T. \& Etumnu, C. (2013). Contribution of agriculture to economic growth in Nigeria. The 18th Annual Conference of the African Econometric Society (AES) Accra, Ghana at the session organized by the Association for the Advancement of African Women Economists (AAAWE), 22nd and 23rd July, 2013.

Ojo, O. (2009). Impact of microfinance on entrepreneurial development: The case of Nigeria. The International Conference on Economics and Administration. University of Bucharest, Romania

Okolie, A.M.N (2009). The contradictions of development in post-colonial African states. Tropical Focus. The International Journal Series on Issues, vol. 10, no 1, January, Pp. 1-15.

Omorogiuwa, O., Zivkovic, J. \& Ademoh, F. (2014). The role of agriculture in the economic development of Nigeria. European Scientific Journal, vol.10, No.4.

Oviasuyi, P. O., Idada, W \& Isiraojie, L. (2010). Constraints of local government Administration in Nigeria. Journal of Social Sciences, 24(2): 81-86 (2010).

Reddy, P. S. (2016). Localizing the sustainable development goals (SDGs): The role of local government in context. African Journal of Public Affairs, Vol. 9 No. 2.

Roberts, P. (1993). Managing the strategic planning and development regions: lessons from an European Perspective. Regional Studies, 27, pp. 759-768.

Teker, S. and Teker, D. (2012). Tourism projects financing: A public-private-partnership model. Business Management Dynamics, Vol. 2, No. 5, Nov. Pg. 5-11.

Trousdale, W. (2005). Promoting local economic development through strategic planning: The local economic development series. Volumes 1 to 5 . Nairobi. Kenya. UN-Habitat.

United Nations Development Group (2015). Localizing the post-2015 development agenda: Dialogues on implementation. New York. Retrieved from https://www.uclg.org/sites/default/files/dialogues_on_localizing the post-2015 development agenda.pdf, on 26/07/2016.

UN-HABBITAT (2009). International guidelines on decentralization and access to basic services for all. Retrieved from https://www.uclg.org/sites/default/files/guidelines_0.pdf, on 21/10/2016

United Nations Human Settlements Programme (2005). Promoting local economic development strategic planning. Volume 1: Quick Guide. Retrieved from https://www.natcapsolutions.org/LASER/LASE R_Ecoplan-Guide.pdf, on 17/04/2017.

UNWTO (2016). UNWTO tourism highlights 2016 edition. Retrieved from https://www.eunwto.org/doi/pdf/10.18111/9789284418145, on 01/12/2017

Venkateswarlu, G. \& Jayalakshmi, M. (2016). Public-private-partnership in tourism sector. International Journal of Management, Information Technology and Engineering. Vol. 4, Issue 1, Jan 2016, 1-6.

World Bank (2003). Local economic development: LED quick references. Prepared by the World Bank Urban Development Unit.

World Bank (2003). Local economic development: A primer: Developing and implementing local economic development Strategies and Action Plans. Washington DC: World Bank.

World Bank (2005). World development indicators. Washington, D.C., World Bank.

World Bank (2007). Local economic development. World Bank. Washington DC. Retrieved from www.worldbank.org, on 13/01/2015.

World Bank. (2007). World development report: agriculture for development. Washington DC. Retrieved from https://siteresources.worldbank.org/INTWDR2008/Resources/WDR_00_book.pdf, on 5/10/2017.

Zaaijer, M. and Sara, L.M. (1993) Local economic development as an instrument for urban poverty alleviation: a case from Lima, Peru. Third World Planning Review, 15 (2):127-142. 


\section{Appendixes}

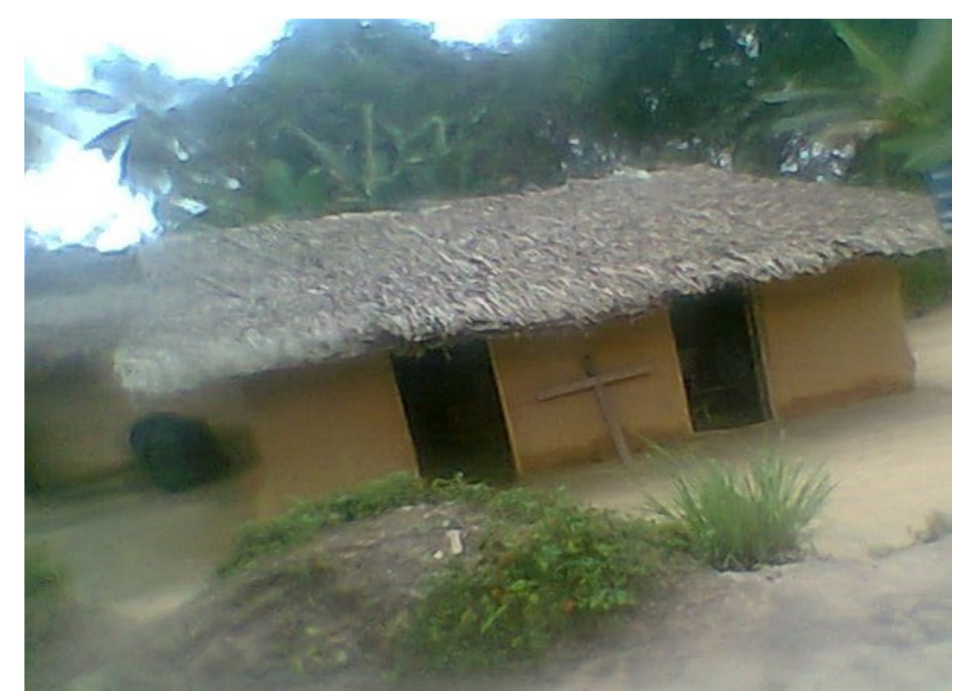

Fig. 1: A typical mud house in Creek Town village of Odukpani LGA

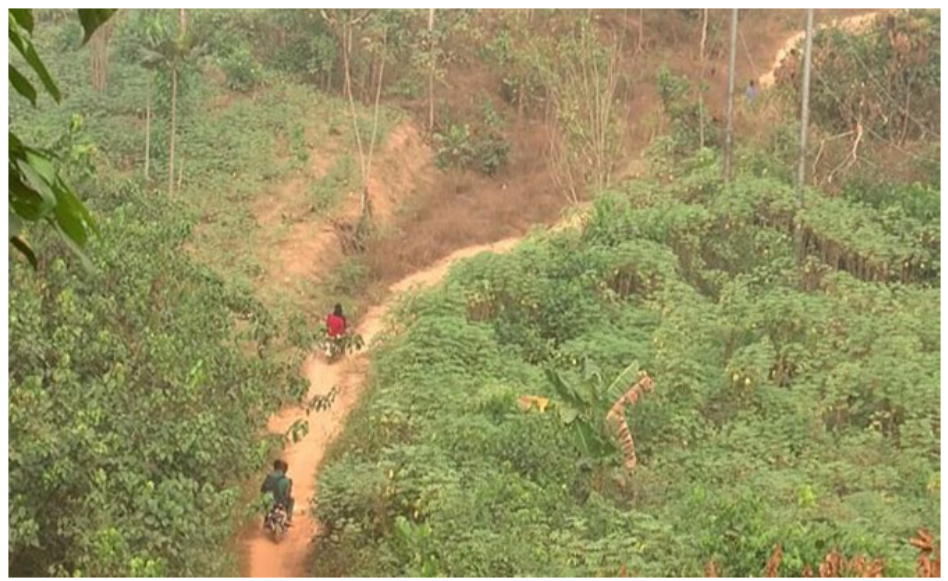

Fig. 2: Image of the only Road Access to Ekpene Eki Community in Odukpani LGA

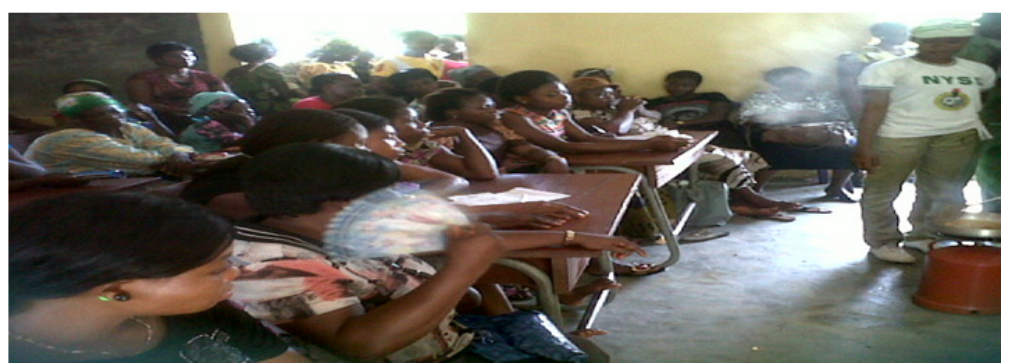

Fig. 4: Cross Section of Participants during the Skill Acquisition Program in Eseku Village 


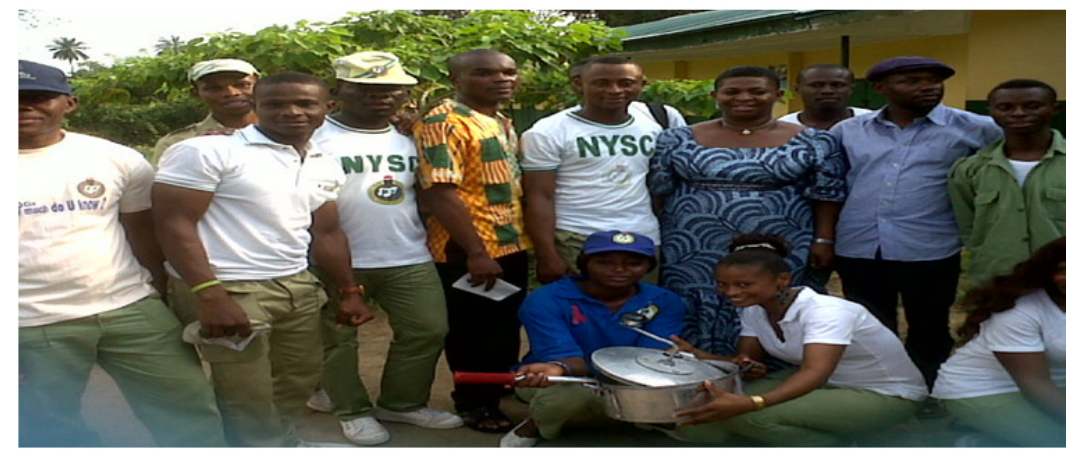

Fig. 5: The organizer of the program, Nnamani Kelechi Elijah in a group photograph with the Wife of the Deputy Governor of Cross River State, Mrs. Glory Cobhams, the Councilor of the Creek Town Ward, Rt. Hon. Ani Ekpenyong Asuquo and other colleagues after the program.

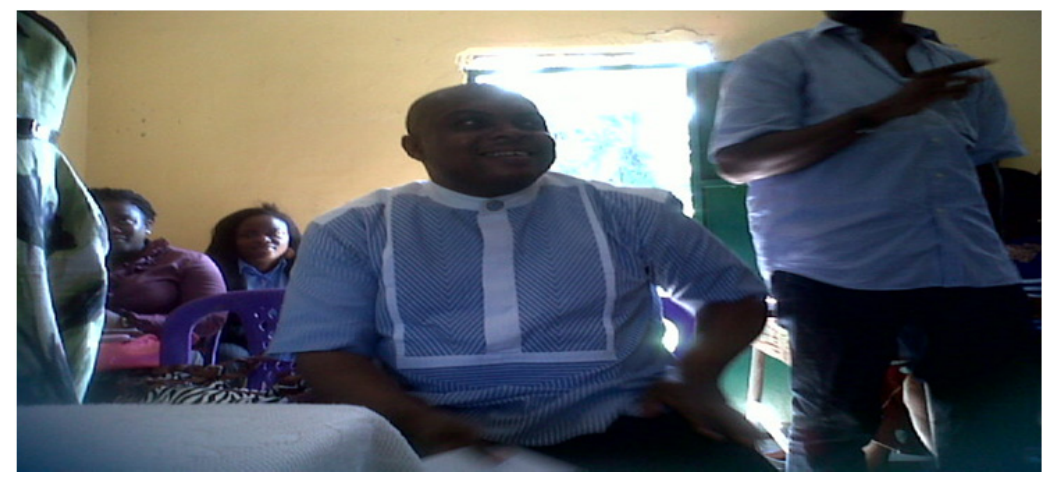

Fig 6. The then General Manager of Cross River State Microfinance \& Enterprise Development Agency, Mr. Louis Ibok during the Skill Acquisition Program at Eseku in Creek Town

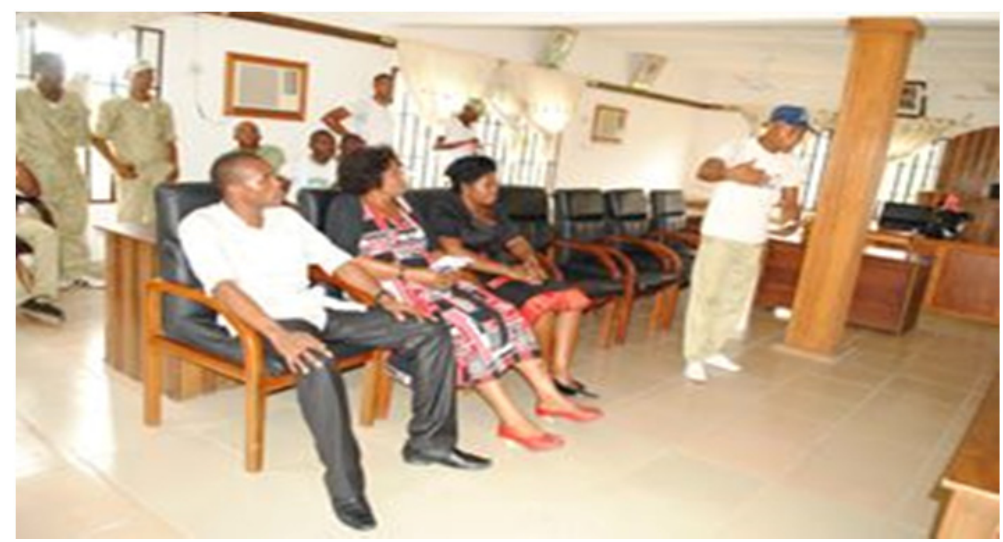

Fig. 7: Nnamani Kelechi Elijah educating the Odukpani Legislative Council on their role towards the actualization of the Strategic Framework for Sustainable Wealth Creation 


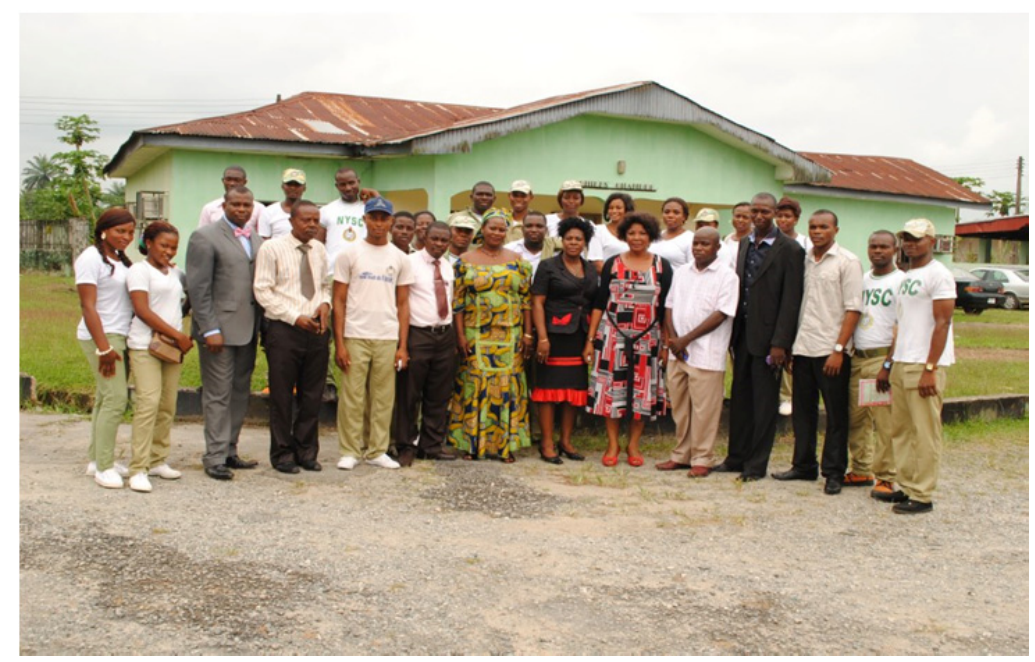

Fig. 8: Nnamani Kelechi Elijah in group photograph with Odukpani Local Government Legislative Council and NYSC Members 